\title{
Correlates of Career Adaptability among Academic Staff in Selected Universities in Nairobi County, Kenya
}

\author{
Maria Ntarangwe, Stephen Asatsa (PhD), Elijah Macharia Ndung'u ( $\mathrm{PhD})$ \\ Department of Psychology, The Catholic University of Eastern Africa, Kenya
}

\begin{abstract}
The academic staff in the university is a vital component in enhancement of academic affairs in any university. Due to the unending changes and dynamics that increase pressure and work related stress that academic staffs are subjected to, they are required to develop high levels of adaptability in their careers to enhance creativity so that they remain relevant. The study sought to establish the correlates of career adaptability among the academic staff in selected universities in Nairobi County, Kenya. The study had several findings: There were high score in the four factors of adaptability including concern, curiosity, control and confidence. The highest score was recorded in concern (Mean= 4.24 and standard deviation 0.60) this was followed by control $($ Mean $=$ $4.25 \pm .58)$. Confidence amongst academic staff was slightly low $($ Mean $=4.12 \pm .57)$. However the lowest was curiosity (Mean = $4.12 \pm .61)$. Generally, the academic staff were adaptable to their work. The research also found out that career adaptability reduced with increase in age. However, it generally increased with the level of education and years of experience. The female gender scored higher than male in most of the constructs of adaptability. There were very slight differences in mean scores in career adaptability based on the type of university. However, a higher level of adaptability was noted in academic staff in private university compared to their counterparts in public university. The study therefore recommended that employers look out for levels of concern, curiosity, confidence and control of employees during recruitment so as to get adaptable employees. Self awareness for employees is necessary to help determine their levels of adaptability. Employers too must prompt acquisition of soft skills in the employees in order to help their employees be more adaptable and hence perform better in their duties.
\end{abstract}

Key words: Career Adaptability, Academic staff, Concern, Curiosity, Control, Confidence.

\section{BACKGROUND}

$\mathrm{G}$ lobally, research has indicated that work settings requires that employees deal with changing responsibilities and situations. In the recent Covid-19 pandemic experienced throughout the world, Chen, Fang, Liu, Pang, Wen, Chen and $\mathrm{Gu}$ (2020) did a research in China. They observed that many people had great difficulties in smoothly adapting to the changing nature from offline work to online duties assigned to them. Generally, career adaptability is becoming one of hottest research topic in the field of careers in recent years.

In the African context, most African economies are categorized as emerging economies. In such economies, personal adaptability that enhance adaptation to the changing economy is becoming an area of concern especially when observed alongside other variables. In Ghana for instance, Delle and Searle (2020) examined the relationship between developmental leadership, career optimism, and career adaptability, and the potential moderating role of career optimism. Data was collected from workers pursuing an MBA program in leadership and other business courses in a Ghanaian University. The study comprised 210 workers enrolled in an MBA program pursuing courses in leadership and business who voluntarily completed a paper-based survey on developmental leadership, career adaptability, and career optimism. Results showed that developmental leadership and career optimism relates positively to career adaptability. In the same country young people still being centre of interest, Nyarko, Peltonen, Kangaslampi and Punam (2020) investigated the protective mental health function of high emotional intelligence (EI), and cognitive skills (CS) among Ghanaian adolescents when exposed to stressful life-events and violence. A direct effect was found between low level of EI and CS and high level of mental health problems.

In Kenya, it is quite notable that enrollment at Higher education of learning has been rapidly increasing in the last decades. The World Bank (2019) noted that the number of universities is constantly increasing. This increase has definitely posed a challenge to relevant stakeholders to mobilize the resources needed to support the increase in the numbers enrolled in these institutions of higher education. This is inclusive of more universities and hence more human resource who are the university employees. All these changes call for adaptability. Mwangi, Mukulu and Kabare (2011) noted that the trend today in Universities is emphasizing reputation and key performance indicators including ranking of universities. New trends of education are directing towards this change and Vice Chancellors and Presidents of the universities strive hard to realize such aspirations. To fulfill such purposes universities need to transform to adopt better ways of operation. Their research therefore analyzed the significance of emotional intelligence on transformational leadership in public universities in Kenya. They carried out a survey in four public universities and data collected showed that emotional intelligence is significant in transformational leadership. 
Employees in Nairobi, who work in the capital city of Kenya as well as heart of economy, education and employment have their fair share of need for adaptability. Wainaina, Kabare and Mukulu., (2014) reviewed literature related to determinants of employee adaptability to transformational change in commercial banks in Kenya. They noted that resistance to transformational change was seen as one of the major impediments to organizational growth and expansion, due to its negative repercussions. Their immediate goal was to enhance the employee ability to adapt to the change process with ease.

Academic staff can be considered the major resource in institutions of higher learning (Alfagira, Zumrah, Noor, \& Rahman, 2017). Bearing in mind that a university is a learning institution, this basically means that although the other administrative and supportive areas are quite key, the academic sector surpasses them. In most universities for example, they are charged with the responsibilities of teaching, supervising of students projects, mentoring, community service and research amongst other responsibilities. Su and Wood (2012) identify three criteria of a successful academic staff including: reflecting on what an individual does so as to be more aware of self and students, engaging in proper communication with students in order to understand them and thirdly having specialized expertise in content and methodology in their area of specialization.

Technologically, there is no doubt too that the world is changing. Right from the onset, robots were purposed to replace people in the workplace. This has surely been evident in developed countries and is beginning to crop up in some developing countries as well over the last century. When the skill that workers possess is less advanced, it is very easily replaced by technology. This is due to the increased demand of advanced cognitive, socio behavioral, and adaptability skills. . (World Bank, 2019).

In the case for instance of new technology, institutions and companies stuck in the old ways are outsmarted by the ones that adjust easily. Employers in these institutions and companies therefore seek to employ people who are highly adaptable. Getting adaptable is a soft skill that is key in getting someone hired. In the current world, employee engagement is considered the most important feature for an organizations competitiveness and success. Engaged employees are highly energized and resilient in performing their job; put their heart into their jobs with persistence and willingness to invest effort; exhibit strong work involvement along with experiencing feelings of significance, enthusiasm, passion, inspiration, pride, excitement, and challenge from their work; and fully concentrate and immerse themselves in their work without noticing that time passes (Margaretha, Widiastuti, Zaniarti \&Wijaya, 2018). As a soft skill, it requires that one has the ability to learn quickly and apply that learning in getting solutions. Due to the increased automatization at work, it is anticipated that jobs will be less routine and hence more attention therefore on the human resource will be placed on innovation, creativity and imagination which may not be possibly automated. In the $21^{\text {st }}$ century therefore, social and emotional skills like altruism, engagement, enthusiasm, innovation, self-discipline and stability are amongst the key component of employability skills (Chernyshenko, 2018).

Robots are taking over thousands of routine jobs and hence this will surely reduce opportunities in low-skill jobs. Many jobs today, and many more in the near future, will necessitate that one is able to combine technological knowhow, problem-solving, and critical thinking as well as soft skills such as perseverance, collaboration, and empathy (World Bank, 2019). Despite the fact that cognitive skills are key for employability, they do not compensate for social and emotional skills that are not adequate. Chernyshenko (2018) suggests that it is absolutely necessary to expand the traditional policy focus on cognitive skills and to embrace a more holistic approach by better supporting children and adults in developing and nurturing social and emotional skills. Hence social and emotional skills are quite relevant in as far as policy interest issues are concerned. One of the soft skills given focus in this research is adaptability. To be competent in far as adaptability is concerned means that an individual is flexible in accepting change, adjustable to multiple demands, and can easily adapt to new situations. One therefore remains focused on their goals, but at the same time adjust to the various ways of achieving those goals. Adaptability reduces being emotionally disturbed by unexpected eventualities. Instead of dwelling on a problem, an adaptable person focuses on how to get solutions and refine strategies. The focus remains in the bigger picture therefore based on this strategies.

Career adaptability has been defined by different scholars using different constructs. Savickas (2012) gives focus to concern, curiosity, control and confidence. This research utilized these constructs to determine career adaptability of academic staff. Concern involves being conscious about and making plans for forthcoming transitions, with a hopeful attitude with respect to the future (Santilli et al., 2017). All employers would wish to have employees who are not only concerned with the present but those who are future oriented. Creed, Fallon, \& Hood (2008) define career concern as individual views with regard to the current career and the ability to focus and visualize how the future career will be like. All the definitions of career concern therefore give prominence to a person's ability to plan and prepare for the current and future career. According to Savickas \& Porfeli (2012), concern is the ability to look ahead and plan for the future. All the academic staff work to prepare graduates for the future or impart knowledge, skills and attitude for the students already on the job.

Career curiosity is another construct of career adaptability. It refers to an individual's ability to explore, discover and find information that are related to the development of the career (Savickas, 2005). Curiosity 
concerns exploring the self and the environment. An individual with a lot of curiosity is always alert, ready and ever doing research like reading materials in his/her area of specialization, attending seminars and workshops to help build and boost her career, seeking advice and more information form exerts and internet on his/her career. Curiosity also refers to the ability of an individual to engage in self -exploration based on various roles and tasks. Being in the academic area where there is production of knowledge every day, an academic staff requires to be curious to remain relevant.

Control is the third aspect of career adaptability. According to Savickas, (2005) career control refers to the ability to take charge and be in a position to construct and build own career. Control involves owning the future and feeling able to make suitable career-related decisions. A person with career control is able to decide the type of job or job to take based on his/her own preferred parameter. This ability does not prevent them from associating with or receiving advice and guidelines from other people but these people always have the last say meaning they are the ones to make the final decision at the end by themselves. Control also deals with an individual's ability to feel that he/she has the role of shaping his/her future life. In the university set up control involves being in charge of a person's job definition.

Confidence is yet another construct in measuring career adaptability. According to Savickas (2012) career confidence is the ability to overcome the obstacles and the challenges encountered on the way to success. This ability gives the person the approach, solve and deal with challenges amicably in their places of work. Confidence is trust and belief that an individual possess the potential to implement their own choices and at the end achieve certain set goals in life. Finally, confidence concerns problem-solving skills and resources to adequately face difficulties, challenges, and impediments. Challenges are common in the academic set up where knowledge has to be created and solutions to societal problems formulated.

\section{METHODS}

This study employed a descriptive survey design. According to Orodho (2009), a descriptive survey refers to a data collection method that collects data from the sampled population through the use of questionnaires and interviews. This study aimed at collecting data with regard to individuals' opinion, attitudes, behaviours and habits, hence descriptive survey research design was appropriate. When asking participants about their views, opinions and behaviours, the participants give a self- report which in turn would require collection of quantifiable information (Mugenda, 2003). This design was deemed fit for this study because the study's main aim was to gather information on various correlates of career adaptability of the academic staff in universities in Nairobi County, Kenya.
The goal of descriptive research according to Nassaji, (2015) is to describe a phenomenon and its characteristics. This study sought to investigate the correlates of career adaptability among the academic staff in selected universities in Nairobi County, Kenya. In order to obtain this information, survey tools, precisely questionnaires were used to gather data. Data was collected using the Career Adapt-Ability Short scale that was distributed to 201 participants who had been sampled using a two-stage cluster sampling method. The data was collected in three universities and analyzed quantitatively, using frequencies, percentages, averages, means and standard deviation so as to determine the extent to which the predictors influenced emotional intelligence. A bivariate analysis was run to determine if there were any differences in the learners' responses based on their age, gender, level of experience, academic achievement and type of university that they were teaching.

\section{The Study Area}

The study was conducted in universities in Nairobi County. Nairobi is the capital city of Kenya and one of Africa's key financial, business, transport, communications, nongovernmental organization, and diplomatic capitals. Nairobi City County consists of 17 Sub counties and 85 wards. It borders Machakos County, Kiambu County and Kajiado County, and covers an area of 696 square kilometers. From the 2019 population census, the County population is estimated at $4,397,073$. The research will be done in private and public universities in Nairobi County.

Nairobi County was selected due to the fact that being the capital city of Kenya, it has a variety of universities as well as a mixed population of people coming from different parts of the world. Universities that are in Nairobi which is the city's capital implies more pressure for the employees to meet their cost of living and hence most of them find themselves teaching in more than one university due to the proximity and accessibility from one university to another.

\section{Study Population}

According to CUE, (2019), the total number of universities in Kenya stands at 71. The 71 Higher institutions of learning constitutes of 37 private and 34 public universities. However in Nairobi County, only 8 private universities and 3 public universities were chattered (CUE 2019).

\section{Sampling Procedures and Sample Size}

Sampling procedure refer to the process of selecting a number of individuals for a study in order to ensure that the individuals selected represent the large group from which they were selected (Kamau, Githi \& Njau, 2014). According to Mugenda (2009) a sample size of between 10 and $30 \%$ is a good representation of the target population and hence the researcher assumes that proposing the maximum limit of $30 \%$ in this study was be adequate for selecting the universities to be considered. Names of the universities were written on pieces of paper and 1 public and 2 private universities were 
selected. The target population from the three universities selected was 403 (University Human resource managers, 2020).

To determine the sample size for the first phase of the research, Taro Yamane (Yamane, 1973) formula with $95 \%$ confidence level will be utilized. The calculation formula of Taro Yamane is presented as:

$$
\begin{aligned}
\mathbf{n} & =\mathrm{N} / 1+\mathrm{N}(\mathrm{e})^{2} \text { Where }: \\
\mathrm{n} & =\text { sample size required } \\
\mathrm{N} & =\text { number of people in the population } \\
\mathrm{e} & =\text { allowable error }(\%) \\
\mathrm{n} & =403 / 1+403 \times 0.0025=\mathbf{2 0 1}
\end{aligned}
$$

\section{Data Collection Instruments}

To measure Career Adaptability, the Career AdaptAbilities Scale Short Form developed by Maggiori, Rossier, \& Savickas, (2017). This scale is a short form of Career AdaptAbilities Scale that was developed by Savickas and Porfeli (2012). The CAAS - International Form 2.0 contains 24 items that combine to form a total score which indicates career adaptability (Savickas \& Porfeli, 2012). An international team of vocational psychologist from 18 countries adopted a multicentric approach to jointly develop the CAAS (Duarte \& Rossier, 2008). The scale comprise 12 items which represent Concern, Control, Curiosity and Confidence subscales to measure career adaptability. On scoring, Participants responded to each item using a 5-point Likert-type scale ranging from 1 which is not a strength to 5 which is greatest strength. The researcher opted to use the CAAS-SF due to its brevity and convenience for the academic staff who would be expected to fill in the form amidst their tight schedule. The questionnaire was pilot tested to establish its validity. To establish internal consistency of the instrument, reliability was determined and Cronbach's alpha coefficient was 0.812 .

\section{RESULTS}

The overall scores were obtained by averaging the total score for the 4 items and obtaining the means. Scores ranging from 1 to 5 were categorize as follow: less than 2.5 indicates low emotional intelligence and more than 2.5 indicate high career adaptability. Scores ranging from 1 to 5 were categorize as follow: less than 2.5 indicates low competence and more than 2.5 indicate high competence on the Career Adaptability subscales.

\section{Age Difference in Career Adaptability .}

The study sought to examine the way in which the

\begin{tabular}{|c|c|c|c|c|c|}
\hline \multicolumn{6}{|c|}{ Report } \\
\hline \multicolumn{2}{|c|}{$\begin{array}{c}\text { Age of } \\
\text { Participants }\end{array}$} & $\begin{array}{c}\text { Career } \\
\text { Adaptabi } \\
\text { lity } \\
\text { (Concern }\end{array}$ & $\begin{array}{c}\text { Career } \\
\text { Adaptabi } \\
\text { lity }\end{array}$ & $\begin{array}{c}\text { Career } \\
\text { Adaptabi } \\
\text { lity } \\
\text { (Curiosit }\end{array}$ & $\begin{array}{c}\text { Career } \\
\text { Adaptabil } \\
\text { ity } \\
\text { (Confiden }\end{array}$ \\
\hline \multirow{3}{*}{$\begin{array}{c}18- \\
28 \\
\text { year } \\
\text { s }\end{array}$} & Mean & 4.5000 & 4.6667 & 4.0833 & 3.8333 \\
\hline & $\mathrm{N}$ & 4 & 4 & 4 & 4 \\
\hline & $\begin{array}{c}\text { Std. } \\
\text { Deviati } \\
\text { on }\end{array}$ & .43033 & .27217 & .73912 & .33333 \\
\hline \multirow{3}{*}{$\begin{array}{c}29- \\
39 \\
\text { yea } \\
\text { rs }\end{array}$} & Mean & 4.3140 & 4.3140 & 4.0386 & 4.0821 \\
\hline & $\mathrm{N}$ & 69 & 69 & 69 & 69 \\
\hline & $\begin{array}{c}\text { Std. } \\
\text { Deviati } \\
\text { on }\end{array}$ & .54198 & .57702 & .64305 & .58132 \\
\hline \multirow{3}{*}{$\begin{array}{c}40- \\
50 \\
\text { yea } \\
\text { rs }\end{array}$} & Mean & 4.2393 & 4.1880 & 4.2009 & 4.1966 \\
\hline & $\mathrm{N}$ & 78 & 78 & 78 & 78 \\
\hline & $\begin{array}{l}\text { Std. } \\
\text { Deviati } \\
\text { on }\end{array}$ & .62626 & .59723 & .58440 & .57468 \\
\hline \multirow{3}{*}{$\begin{array}{c}51- \\
61 \\
\text { yea } \\
\text { rs }\end{array}$} & Mean & 3.8095 & 4.1429 & 3.9524 & 4.0000 \\
\hline & $\mathrm{N}$ & 14 & 14 & 14 & 14 \\
\hline & $\begin{array}{l}\text { Std. } \\
\text { Deviati } \\
\text { on }\end{array}$ & .66299 & .55028 & .58261 & .55470 \\
\hline \multirow{3}{*}{$\begin{array}{c}62- \\
72 \\
\text { yea } \\
\text { rs }\end{array}$} & Mean & 3.6667 & 3.6667 & 4.3333 & 4.3333 \\
\hline & $\mathrm{N}$ & 1 & 1 & 1 & 1 \\
\hline & $\begin{array}{l}\text { Std. } \\
\text { Deviati } \\
\text { on }\end{array}$ & . & . & . & . \\
\hline
\end{tabular}
age the participants influence their career adaptability. Furthermore, the trends of changes of age in relation to the different constructs of adaptability are discussed in figure 1.
Table 1: Age difference in Career adaptability

Four factors of career adaptability were measured including concern, control, curiosity and confidence. Concern as a factor of career adaptability was highest for the participants ranging from $18-28$ years $($ Mean $=4.50)$. This implied that the academic staff at this age thought about their future and prepare well for it. Similarly they critically were aware of their educational and career choices. On the other hand however participants at the age of 18-28 years scored lowest in career adaptability on the issue of confidence (Mean $=3.83$ ). Compared to the other participants in the research the low confidence could be attributed to little experience at work since they were probably new graduates and still need to build up confidence from experience in comparison with their counterparts in age 62-72 years who scored highest in terms of confidence $($ Mean $=4.33)$. 


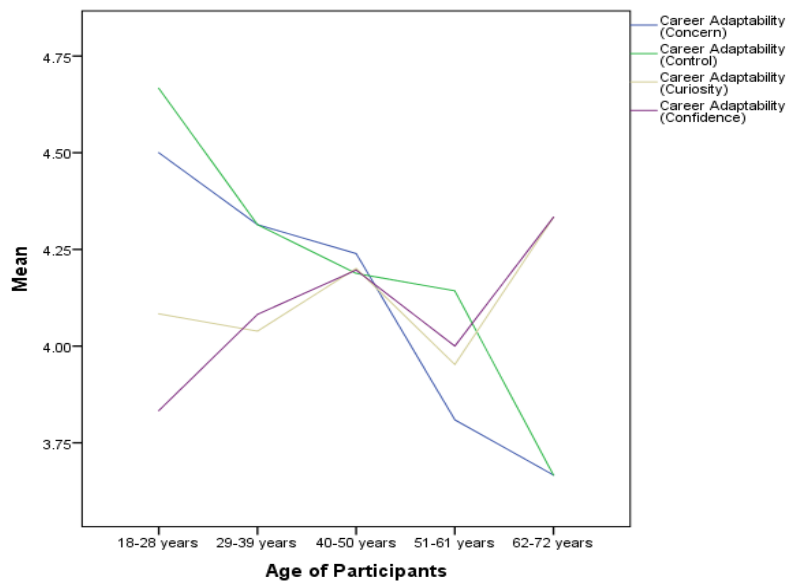

Figure 1

In terms of the patterns that were observed, there was notably a reduction in the mean score in areas of concern with the increase in age. From the four age brackets, the means for concern reduced from 18-28, $($ Mean $=4.50), 29-39$ (Mean $=$ 4.31) 40-50 $($ Mean $=4.23), 51-61($ Mean $=3.80)$ to $62-72$ (Mean =3.67). This pattern clearly indicated that the older the academic staff grew, the less concerned they became about their job. With advancement in age, it implied that the employees became less conscious about their future and making plans for forthcoming transitions. The reduction could be attributed to the fact that as people grow older in their careers the concern to prepare for the future reduces since most start getting comfortable where they already are. The familiarity with the work also may reduce personal initiative as people tend to get comfortable with routine as one progresses age wisely. On the same length, the age brackets given in this line record the time when employees get more engaged with family and other personal developments that may affect the levels of their concern and control at work place.

Similarly the reduction is witnessed in the aspect of control where at age 18-28 $($ Mean= 4.67), 29-39 $($ Mean $=$ $4.31), 40-50 \quad($ Mean $=4.18), 51-61($ Mean $=4.14)$ to $62-72$ (Mean =3.67). The findings in the study showed that, as employees advance in age, they no longer own the future and they therefore stop feeling able to make suitable career-related decisions. Reduction in control meant that the employee reduced their ability to feel that he/she has the role of shaping his/her future life as their age advanced.

The curiosity construct did not consistently reduce with age. The trend changed where it reduced from years 18$29($ Mean $=4.08)$ to $29-39($ Mean $=4.04)$. This reduction implied that the employee's ability to explore, discover and find information went down. They no longer had much interest to explore themselves and the environment. There was also reduction in their degree of alertness, desire for research, gaining new knowledge from seminars and workshops or seeking advice and more information form experts. However, the means increased at age 40-50 ( Mean =
4.20). This is where life was more defined as individual sought to settle and learn new things in the paths that their life had taken. Furthermore, at age 51-61 years, a reduction was evident $($ Mean $=3.95)$. At the late stages of life however, curiosity again started being witnessed where employees planned to retire yet new things seemed to come their way.

On the issue of confidence, the mean increased with age. This therefore meant, as people grew older, they became more confident. This trend however, is with the exception of age 51-61 (Mean $=4.00$ ) where a decline was experienced. This implied that as the age advanced the employees levels of confidence went up. From 18-28(Mean= 3.83), 29-39 (Mean $=4.08), 40-50$ (Mean $=4.20)$, to 62-72 $($ Mean $=4.33)$. From the results of the finding therefore, it is apparent that as employees grew older, their ability to overcome the obstacles and the challenges encountered on the way to success increased. Moreover, they were more able to approach, solve and deal with challenges amicably in their places of work. They developed trust and belief in their potential to implement their own choices and achieve certain set goals in their work place.

\section{Gender Difference in Career Adaptability}

The study targeted to examine the way in which gender of the participants influence their career adaptability. Table 13 shows the mean differences in terms of how people of different gender develop career adaptability

Table 2: Gender differences in career adaptability

\begin{tabular}{|c|c|c|c|c|c|}
\hline \multicolumn{6}{|c|}{ Report } \\
\hline \multirow{2}{*}{$\begin{array}{c}\text { Gender of } \\
\text { Participants }\end{array}$} & $\begin{array}{c}\text { Career } \\
\text { Adaptabi } \\
\text { lity } \\
\text { (Concer } \\
\text { n) }\end{array}$ & $\begin{array}{c}\text { Career } \\
\text { Adaptabi } \\
\text { lity } \\
\text { (Control } \\
\text { ) }\end{array}$ & $\begin{array}{c}\text { Career } \\
\text { Adaptabi } \\
\text { lity } \\
\text { (Curiosit } \\
\text { y) }\end{array}$ & $\begin{array}{c}\text { Career } \\
\text { Adaptabi } \\
\text { lity } \\
\text { (Confide } \\
\text { nce) }\end{array}$ \\
\hline \multirow{4}{*}{ Male } & Mean & 4.2154 & 4.2480 & 4.0407 & 4.0488 \\
\cline { 2 - 6 } & N & 82 & 82 & 82 & 82 \\
\cline { 2 - 6 } & $\begin{array}{c}\text { Std. } \\
\text { Deviat } \\
\text { ion }\end{array}$ & .54527 & .55632 & .58652 & .58119 \\
\hline \multirow{4}{*}{$\begin{array}{c}\text { Fem } \\
\text { ale }\end{array}$} & Mean & 4.2579 & 4.2421 & 4.1786 & 4.1984 \\
\cline { 2 - 6 } & N & 84 & 84 & 84 & 84 \\
\cline { 2 - 6 } & $\begin{array}{c}\text { Std. } \\
\text { Deviat } \\
\text { ion }\end{array}$ & .65727 & .61082 & .63255 & .55517 \\
\hline
\end{tabular}

The findings show that there were extremely slight variation in the means of the scores where women seemed to score slightly higher than men in certain constructs and men exceeded women in others. On the issue of concern, women scored means that exceeded that of men. The women score was $($ Mean $=4.26)$ while men $($ Mean $=4.22)$,

On the issue of control however, men scored slightly a higher Mean $=4.25$, while women Mean $=4.24$. This therefore meant that the men are keener in taking responsibilities for their actions and can count on themselves. 
Women were more curious when it came to learning new things and discovering their future. On computing their means, that of women (Mean $=4.18$ ) exceeded that of men $($ Mean $=4.04)$. On the same note, women $($ mean $=4.20)$ exceeded men $($ mean $=4.05)$ in confidence. This therefore implied that women were more adaptable to their careers in more constructs than men.

\section{Educational Level Differences in Career Adaptability.}

The study sought to establish whether the level of education of an academic staff influenced their career adaptability. To further explain the trend, results were presented in figure 2 .

Table 3: Education levels differences in career adaptability

\begin{tabular}{|c|c|c|c|c|c|}
\hline \multicolumn{2}{|c|}{$\begin{array}{l}\text { Highest Level of } \\
\text { Education }\end{array}$} & $\begin{array}{c}\text { Career } \\
\text { Adaptab } \\
\text { ility } \\
\text { (Concer } \\
\text { n) } \\
\end{array}$ & $\begin{array}{c}\text { Career } \\
\text { Adaptab } \\
\text { ility } \\
(\text { Control } \\
\text { ) } \\
\end{array}$ & $\begin{array}{c}\text { Career } \\
\text { Adaptab } \\
\text { ility } \\
\text { (Curiosit } \\
\text { y) }\end{array}$ & $\begin{array}{c}\text { Career } \\
\text { Adaptabi } \\
\text { lity } \\
\text { (Confide } \\
\text { nce) }\end{array}$ \\
\hline \multirow{3}{*}{$\begin{array}{l}\text { Gradu } \\
\text { ate }\end{array}$} & Mean & 4.1600 & 4.3067 & 3.9867 & 3.9867 \\
\hline & $\mathrm{N}$ & 25 & 25 & 25 & 25 \\
\hline & $\begin{array}{c}\text { Std. } \\
\text { Deviat } \\
\text { ion }\end{array}$ & .73987 & .62302 & .64176 & .56503 \\
\hline \multirow{3}{*}{$\begin{array}{c}\text { Maste } \\
\text { r's } \\
\text { Degre } \\
\text { e }\end{array}$} & Mean & 4.2572 & 4.1775 & 4.1159 & 4.1087 \\
\hline & $\mathrm{N}$ & 92 & 92 & 92 & 92 \\
\hline & $\begin{array}{c}\text { Std. } \\
\text { Deviat } \\
\text { ion }\end{array}$ & .57651 & .61414 & .55785 & .55273 \\
\hline \multirow{3}{*}{$\mathrm{PhD}$} & Mean & 4.2576 & 4.3106 & 4.1061 & 4.2500 \\
\hline & $\mathrm{N}$ & 44 & 44 & 44 & 44 \\
\hline & $\begin{array}{c}\text { Std. } \\
\text { Deviat } \\
\text { ion }\end{array}$ & .55155 & .48967 & .68868 & .58458 \\
\hline \multirow{3}{*}{$\begin{array}{c}\text { Post- } \\
\text { Docto } \\
\text { ral }\end{array}$} & Mean & 3.7778 & 4.4444 & 4.4444 & 3.4444 \\
\hline & $\mathrm{N}$ & 3 & 3 & 3 & 3 \\
\hline & $\begin{array}{c}\text { Std. } \\
\text { Deviat } \\
\text { ion }\end{array}$ & 1.01835 & .50918 & 69389 & .19245 \\
\hline \multirow{3}{*}{ Other } & Mean & 4.5000 & 4.8333 & 5.0000 & 4.8333 \\
\hline & $\mathrm{N}$ & 2 & 2 & 2 & 2 \\
\hline & $\begin{array}{c}\text { Std. } \\
\text { Deviat } \\
\text { ion }\end{array}$ & .70711 & 23570 & .00000 & .23570 \\
\hline
\end{tabular}

The findings obtained gave a clear indication that the participants who had other qualifications had scored highest when it came to factors of concern, control, curiosity and confidence in determining career adaptability. (Mean $=4.50$, mean $=4.83$, Mean $=5.00$, Mean $=4.83$ ) respectively. This could be attributed to the low number of participants presented for this category $(\mathrm{N}=2)$. There was also a notable low mean score for concern for academic staff with Post doctoral $($ Mean $=3.78)$ as their highest level of education. This could be due to the fact that most were rather contented with their academic achievements and were slightly settled for the moment with the job.

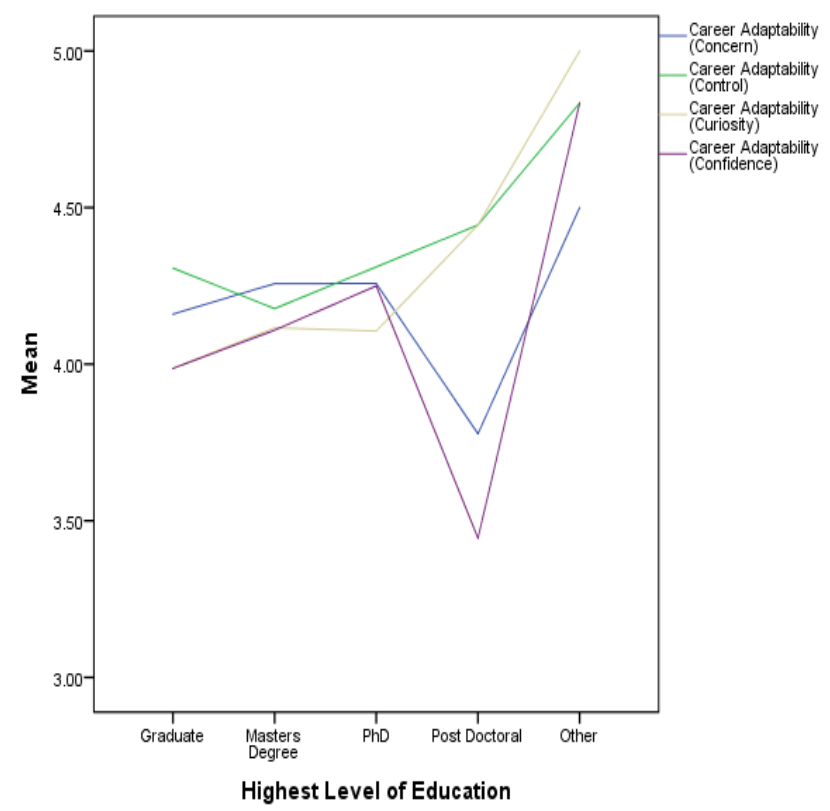

Figure 2

The concern that the academic staff had for the job increased with level of education. This meant therefore, the more one was educated, the more they got concerned about the future and increased sensitivity towards future goal. The score rose from graduate $(\mathrm{Mean}=4.16)$, masters and $\mathrm{PhD}$ level had the same score ( Mean $=4.26$ ) the mean slightly declined with the post- doctoral level (3.78). concern for future at his level reduced indicating that the academic staff probably focused on other things beside their jobs and selfimprovement for future.

The control factor seemingly increased with the level of education from masters to post-doctoral level (Mean $=4.18$ to Mean = 4.83). However, at the graduate level, control and the feeling of being in charge of the situation scored same as the academic staff who had Masters degree ( Mean = 4.31). This therefore implied that the more education one obtained the more they were likely to make decisions by themselves, take responsibility for the various actions at work place and count on themselves.

Curiosity also seemed to increase with the level of education. The more the academic staff gained more knowledge, the more they became curious to learn more and more. This is probably the reason the mean increased from graduate $($ Mean $=3.99)$ to post- doctoral $($ Mean $=4.44)$. Similarly, confidence increased with academic advancement. From graduate $($ mean $=3.99)$ to $\mathrm{PhD}$. $($ Mean $=25)$ however, as in concern, confidence at the post -doctoral level also seemed to reduce ( Mean $=3.44)$.

Generally all the constructs of career adaptability improved as employees advance academically. Since career adaptability is a soft skill that is learnt, the environment and cognitive development could help boost adaptability. The academic environment seem to increase this. 


\section{Teaching Experience Difference in Career Adaptability}

The study deemed it important to examine whether the teaching experience of an academic staff influenced their career adaptability. Alongside the table used to summarize the scores, figure 3 was also used to show trends in the scores.

Table 4: Teaching experiences differences in career adaptability

\begin{tabular}{|c|c|c|c|c|c|}
\hline \multicolumn{2}{|c|}{$\begin{array}{c}\text { Years of } \\
\text { Teaching in the } \\
\text { University }\end{array}$} & $\begin{array}{c}\text { Career } \\
\text { Adaptabi } \\
\text { lity } \\
\text { (Concern } \\
\text { ) }\end{array}$ & $\begin{array}{c}\text { Career } \\
\text { Adaptabi } \\
\text { lity } \\
\text { (Control) }\end{array}$ & $\begin{array}{c}\text { Career } \\
\text { Adaptabi } \\
\text { lity } \\
\text { (Curiosit } \\
\text { y) }\end{array}$ & $\begin{array}{c}\text { Career } \\
\text { Adaptabil } \\
\text { ity } \\
\text { (Confiden } \\
\text { ce) } \\
\end{array}$ \\
\hline \multirow{3}{*}{$\begin{array}{c}0-5 \\
\text { yea } \\
\text { rs }\end{array}$} & Mean & 4.2807 & 4.2456 & 4.1140 & 4.1184 \\
\hline & $\mathrm{N}$ & 76 & 76 & 76 & 76 \\
\hline & $\begin{array}{l}\text { Std. } \\
\text { Deviati } \\
\text { on }\end{array}$ & .60871 & .60460 & .63841 & .59306 \\
\hline \multirow{3}{*}{$\begin{array}{l}6- \\
10 \\
\text { yea } \\
\text { rs }\end{array}$} & Mean & 4.3704 & 4.4074 & 4.2074 & 4.2667 \\
\hline & $\mathrm{N}$ & 45 & 45 & 45 & 45 \\
\hline & $\begin{array}{l}\text { Std. } \\
\text { Deviati } \\
\text { on }\end{array}$ & .46178 & .53129 & .58728 & .57119 \\
\hline \multirow{3}{*}{$\begin{array}{l}11- \\
15 \\
\text { yea } \\
\text { rs }\end{array}$} & Mean & 4.0860 & 4.0430 & 4.0538 & 4.0323 \\
\hline & $\mathrm{N}$ & 31 & 31 & 31 & 31 \\
\hline & $\begin{array}{l}\text { Std. } \\
\text { Deviati } \\
\text { on }\end{array}$ & 66091 & 60701 & .59689 & .50446 \\
\hline \multirow{3}{*}{$\begin{array}{l}16- \\
20 \\
\text { yea } \\
\text { rs }\end{array}$} & Mean & 3.7000 & 4.0000 & 3.7333 & 3.8667 \\
\hline & $\mathrm{N}$ & 10 & 10 & 10 & 10 \\
\hline & $\begin{array}{l}\text { Std. } \\
\text { Deviati } \\
\text { on } \\
\end{array}$ & .61764 & .31427 & .43885 & .47661 \\
\hline \multirow{3}{*}{$\begin{array}{l}21- \\
25 \\
\text { yea } \\
\text { rs }\end{array}$} & Mean & 4.4167 & 4.5833 & 4.3333 & 4.0000 \\
\hline & $\mathrm{N}$ & 4 & 4 & 4 & 4 \\
\hline & $\begin{array}{c}\text { Std. } \\
\text { Deviati } \\
\text { on }\end{array}$ & .73912 & .50000 & .72008 & .72008 \\
\hline
\end{tabular}

From the research findings, all the four aspects of career adaptability seemed to increase in mean in the first years of teaching. The staff with the longest working experience 21-25 years record the highest levels of all the four constructs of adaptability. This therefore attest to the fact that adaptability is a soft skill that a person can acquire through experience. However there is a notable decline in mean for all the four factors of adaptability at the $16^{\text {th }}-20^{\text {th }}$ year of experience that may be onset of fatigue to work as well as familiarity that may breed routine. The staff who have taught for 6-10 years record the highest means of control. (Mean= 4.37) this implies that they are confident enough to pick on duties skillfully.

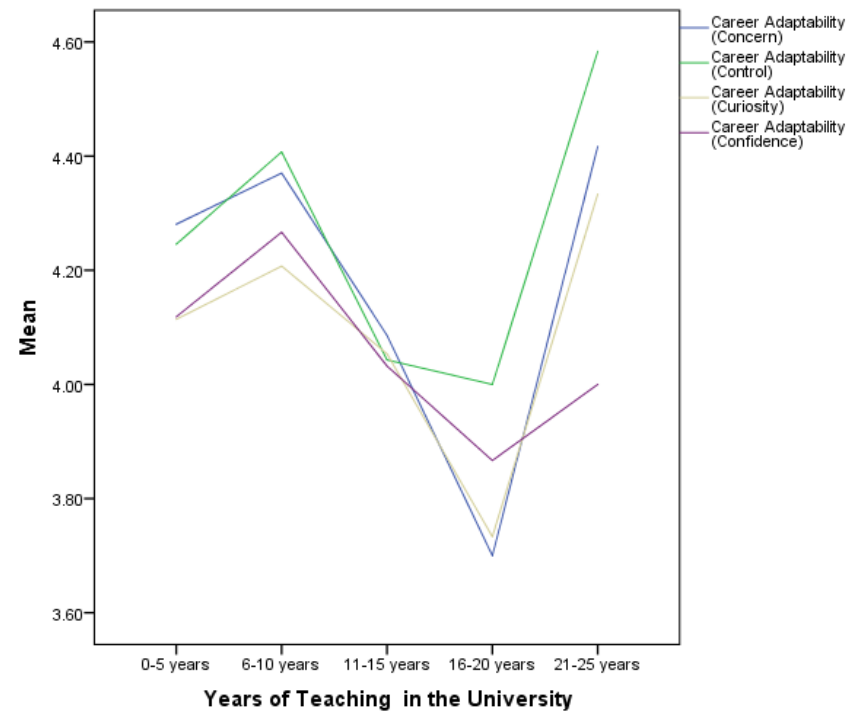

Figure 3

Concern as a construct of adaptability increased between $0-10$ years of experience. $($ Mean= 4.23$)$ to $($ Mean $=$ 4.37) as one got into a new job, they thought about their future in their new assignment. However, from 11-15 years, the concern (Mean $=4.09$ ) was seen to decline as one got used to the job and was therefore less concerned about the future. The trend went on reducing and the concern came up again when one was about to retire after working for 21-25 years $($ Mean $=4.42)$.

Similarly in control factor, those who worked for 0-5 years had a mean of 4.25 and the mean increased to 4.41. However, for those who had worked for 11-15 years reduced to 4.04. This therefore meant that the academic staff started to be in charge of situation only when they worked for 2125 years later.

. For the aspect of curiosity and confidence the means of those who had an experience of 0-5 years increased as they got to 6-10 years of experience. This clearly showed that as a people enter new jobs they tried to adjust to changes to fit into the job. However, the more they got used to the job the more rigid they became in terms of adjusting to oncoming changes.

Furthermore, at 16- 20 years' experience of teaching, they reduced their curiosity in learning new things and opportunities and at the same time were not confident. In the same length, as the academic staff got to 21-25 years of teaching, levels of adaptability in as far as concern, control and curiosity are concerned and confidence level remained high as compared to the subsequent years.

\section{Types of University Difference in Career Adaptability}

The study deemed it important to examine whether the teaching experience of an academic staff influenced their career adaptability. 
Table 5: 1Difference in Career Adaptability in types of university.

\begin{tabular}{|c|c|c|c|c|c|}
\hline Type of & iversity & $\begin{array}{c}\text { Career } \\
\text { Adaptab } \\
\text { ility }\end{array}$ & $\begin{array}{c}\text { Career } \\
\text { Adaptab } \\
\text { ility }\end{array}$ & $\begin{array}{c}\text { Career } \\
\text { Adaptab } \\
\text { ility }\end{array}$ & $\begin{array}{c}\text { Career } \\
\text { Adaptabi } \\
\text { lity }\end{array}$ \\
\hline & Mean & 4.2537 & 4.2360 & 4.1740 & 4.1386 \\
\hline Private & $\mathrm{N}$ & 113 & 113 & 113 & 113 \\
\hline ity & $\begin{array}{c}\text { Std. } \\
\text { Deviat } \\
\text { ion }\end{array}$ & .59474 & .56988 & 63009 & .59215 \\
\hline & Mean & 4.2013 & 4.2642 & 3.9748 & 4.0943 \\
\hline Public & $\mathrm{N}$ & 53 & 53 & 53 & 53 \\
\hline $\begin{array}{l}\text { Univer } \\
\text { sity }\end{array}$ & $\begin{array}{c}\text { Std. } \\
\text { Deviat } \\
\text { ion }\end{array}$ & 62477 & 61449 & .55412 & .52857 \\
\hline & & & & & \\
\hline
\end{tabular}

However little the difference in the mean score seemed, the study established that academic staff working in private universities had higher levels of concern (Mean = 4.25), curiosity (4.17) and confidence (4.14) compared to their counterparts in public universities. Furthermore in public university, the level of control in career adaptability (mean = 4.26) was slightly higher with a mean difference of 0.02 . This is an indication that in private universities the teaching staff are more curious in terms of investing in new opportunities probably compared to public universities where the terms of employment provide more security.

\section{DISCUSSION}

\section{Age Difference in Career Adaptability}

The implication that is found in this demographic characteristic therefor is that there are no conclusive research findings on the relationship between age and career adaptability. The findings in the study indicate that there were considerable differences of career adaptability with regard to age. There was evidence from data that adaptability reduced with age. The younger participant on average scored higher than older participant. However, at the late years that neared retirement, mean scores increased. This therefore implied that older people (62-72 years) were adaptable to changes in the work place

The findings in this study concurred with a research that also proposed that there was an increase in the mean scores of career adaptability as one goes to the lower ages, Rostami, Abedi, Bagnhan and Savickas (2012). They further contend that individuals who begin working at early ages tend to have high levels of career adaptability and strong feelings of attachment towards the institutions they are working for. With time therefore due to familiarity and other factors, employees tend to reduce the strong feelings of attachment towards their work unless this is intentionally prompted.

Ferreira (2012), agreed with this research on the fact that age correlates with control. He notes that this correlation is associated with the fact that during the early career of a person is when they young adults structure their lives as they begin to settle down and increase their commitment towards their job. There are theories that developed in the vocational maturity development models. Rossier Zecca, Stauffer, Maggiori, and Dauwalder (2012) in their theory opposed that age influences career adaptability. Other researchers also disputed the presence of this relationship. They suggested that no significant differences existed in relation to age and career adaptability. (Bakken and Holzemer, 2000; Salamonson, Andrew and Everett, 2009).

\section{Gender Difference in Career Adaptability}

Findings showed that women were more adaptable to their careers than men. This difference in adaptability in terms of gender can be explained in different ways. Males appear to be more hardy committed than their female counterparts (Latif, 2010). This is probably the reason why they can adjust to challenges and dynamics in work. However this also may not be conclusive since even among the same gender there seems to be differences according to race. A research by Ferreira, (2012) revealed that Black women possess higher levels of hardy challenge than their white counterparts

However, gender alone may not determine career adaptability of a person. Many other factors play along. In a study conducted by Kaya (2017) in which investigations were carried out on the effect of risk taking behaviours on career adaptability, it was evident that career adaptation skills and risk taking factors differed based on gender and grade point average, income and student's class.

In as much as this research found out that women tend to have higher scores in concern, curiosity and confidence for their jobs, studies also have revealed that young male adults tend to have superior uncertainty with regard to their career ambitions compared to their female colleagues, males also are dependent more strongly on positive comments and encouragement from their parents (Gutman \& Schoon, 2012). This kind of positive comment could probably be the reason that prompts them to be more concerned and curious and in the long run boosts their confidence

Another study by Ferreira (2012) agree that women are more adaptable and much purposeful in planning for their careers than men. If women are more purposeful and plan well, it therefore would mean they plan because they are concerned about their jobs and curious to get better results and opportunities. This therefore would imply higher adaptability for women than men.

The debate of gender disparities alongside career adaptability has elicited different reports from different researchers where others actually contend that there is no difference. In their research, Maggiori, Johnston, Krings, Massoudi, and Rossier (2013) conclude that there is absolutely no significant relationship between gender and 
career adaptability. This therefore informs the study to look into other factors besides gender. Amongst the factors that the researcher focused on therefore is EI.

Recent research into the relationship between gender and career adaptability is limited and inconclusive. O'Connell, McNeely, and Hall (2008), Havenga (2012), and Rocha (2012), for example, found career adaptability to be significantly related to gender, whereas Hirschi (2009) and Maggiori, Johnston, Krings, Massoudi, and Rossier (2013) found no significant relationship between gender and career adaptability. In terms of gender differences, research (Ferreira, 2012) indicates that women tend to be more adaptable than men. Women also tend to be more purposeful in the planning of their careers than men (Zhang, 2010) while this research found out that men were more adaptable than women

\section{Education Level Difference in Career Adaptability}

The findings obtained gave a clear indication that the participants' level of concern and control decreased with higher levls of education. However the more one advanced in education, the more they were likely to increase their levels of curiosity and confidence. There was also a notable low mean score for concern for academic staff with Post doctoral (Mean $=3.78$ ) as their highest level of education. This could be due to the fact that most were rather contented with their academic achievements and were slightly settled for the moment with the job.

This study therefore concurs with the notion supported by Zacher (2014) who notes other factors that influence career adaptability include a person's level of education, training and academic achievement. This therefore implies the difference in influence that academic achievement may have on the career adaptability of a person. With a good environment also there are high chances of increasing emotional intelligence that may in turn boost adaptability.

Generally most of the constructs of career adaptability measured in this study improved as employees advance academically. Since career adaptability is a soft skill that is learnt, the environment and cognitive development could help boost adaptability. It is therefore of great importance for academic staff to have continued learning to improve issues like their curiosity and hence their career adaptability.

The academic environment on its own may increase adaptability. Generally, the study advocates for academic staff to continue with self- development both cognitively and in soft skill. Both intellectual and emotional intelligence need boosting to enhance adaptability.

\section{Years of Teaching Experience and Career Adaptability}

Findings in this study show that all the constructs of adaptability increase during the first 10 years of employment. However, due to familiarity to the environment and routine, adaptability reduces and therefore at the experience of 16-20 years it is lowest. However, it increases with more time of experience.

The findings in this study are congruent with what Hirschi, (2010) found in an empirical study that the more the years of experience, the higher the level of Career Adaptability. It is therefore worthwhile to note that whether one has experience or not, adaptability can be acquired with the experience as the employee preogress.

Similar to this findings as well, Zacher, (2014), supports the findings of this resarch in asserting that young adults and adults career adaptability is seen as a predictor for subjective career success satisfaction with transition processes. Similarly, Negru-Subtirica \& Pop (2016) also acknowledges that work volition could also affect Career Adaptability

The high levels of adaptability shown by employees who had worked for 21-25 years give clear indication of the role of experience in career adaptability. This is in line with Allen \& Velden, (2011) position that, there is a general consensus concerning the positive influence of work experience during higher education on preparation for the labor transition.

\section{Type of University and Career Adaptability}

Findings in this research indicate that there are little the difference in the mean score of the academic staff in private and public institutions. However, the study established that academic staff working in private universities had higher levels of concern. Furthermore in public university, the level of control was slightly higher. This is an indication that in private universities the teaching staff are more curious in terms of investing in new opportunities probably compared to public universities where the terms of employment provide more security.

\section{CONCLUSION}

Career adaptability of an academic staff correlated with many factors. The correlates in this research included age, gender, level of education, years of experience and type of university the academic staff is working for. It is therefore key for employers to be keen on the trends that appear with the various correlates in order to improve performance. Seminars and workshops may be used to raise curiosity and concern of workers where the concern or curiosity decline with age, level of education or years of experience. Similarly in cases where control is low, responsibility can be given to boost these levels of control. It is therefore vital not only for employers but even employees to be sensitive to their levels of adaptability at work so as to boost performance.

\section{REFERENCES}

[1] Alfagira, S.G., Zumrah, A.R., Noor, K.B., \& Rahman, O.B. (2017). Investigating the factors influencing academic staff performance: A Conceptual Approach. The Career Development Quarterly, 45, 247-259. 
[2] Bakken, S., and Holzemer, W.L. (2000). Relationships between perception of engagement with health care provider and demographic characteristics, health status, and adherence to therapeutic regimen in persons with HIV/AIDs. AIDS Patient Care \& STDs, 14( 4), 189.

[3] Chen H, Fang T, Liu F, Pang L, Wen Y, Chen S, Gu X.( 2020). Career adaptability research: A Literature review with scientific knowledge mapping in web of science. Int J Environ Res Public Health. 17(16). doi: 10.3390/ijerph17165986. PMID: 32824717; PMCID: PMC7459956.

[4] Chernyshenko, O., M. Kankaraš \& F. Drasgow (2018). Social and emotional skills for student success and well-being: Conceptual framework for the OECD study on social and emotional skills", OECD Education Working Papers. 173.

[5] Creed, P. A., Fallon, T., \& Hood, M. (2008). The relationship between career adaptability, person and situation variables, and career concerns in young adults. Journal of Vocational Behavior, 74, 219-229.

[6] Delle, E., \& Searle, B. (2020). Career Adaptability: The role of developmental leadership and career optimism. journal of career development. https://doi.org/10.1177/0894845320930286.

[7] Duarte, M. E., \& Rossier, J. (2008). Testing and assessment in an international context: Cross- and multi-cultural issues. In J. Athanasou \& R. Van Esbroeck (Eds.), International handbook of career guidance (pp. 489-510). Dordrecht: Springer Science.

[8] Feng Su, Margaret Wood, (2012),"What makes a good university lecturer? Students' perceptions of teaching excellence", Journal of Applied Research in Higher Education, 4 (2) pp. 142 - 155.

[9] Ferreira, N. (2012). Constructing a psychological career profile for staff retention. Unpublished doctoral dissertation. University of South Africa, Pretoria, South Africa.

[10] Gutman, L. M., \& Schoon, I., (2012). Correlates and consequences of uncertainty in career aspirations: Gender differences among adolescents in England. Journal of Vocational Behavior, 80 608-618.

[11] Havenga, M. (2012). The relationship between career adaptability and academic achievement in the course of life design counselling (Unpublished master's dissertation). University of Pretoria, Pretoria, South Africa.

[12] Hirschi, A. (2009). Career adaptability development in adolescence: Multiple predictors and effect on sense of power and life satisfaction. Journal of Vocational Behavior, 74, 145- 155.

[13] Kamau, J. N., Njau, M. M., \& Wanyagi, J. (2014). Factors influencing work attitude among ' $y$ ' generation (a case of africa nazarene university. European Scientific Journal, ESJ, 10(10). https://doi.org/10.19044/esj.2014.v10n10p\%p.

[14] Kaya, E. U. (2017). The effect of risk taking behaviors on the career adapt-abilities and its relation with this variable: an observation in terms of personal variables in higher education. The Journal of Academic Social Science Studies, 55, 289-312.

[15] Latif, S. (2010). Effective methods of engaging with black and minority ethnic communities within health care settings. Better Health Briefing 18. Race Equality Foundation.; No. 18.

[16] Maggiori C., Johnstone C., Krings F., \& Rossier J (2013). The role of career adaptability and work conditions on general and professional well-being. Journal of Vocational Behavior 83(3):437-449. DOI: 10.1016/j.jvb.2013.07.001

[17] Maggiori, C., Rossier, J., \& Savickas, M. L. (2017). Career AdaptAbilities Scale-Short Form (CAAS-SF): Construction and Validation. Journal of Career Assessment, 25(2), 312325. https://doi.org/10.1177/1069072714565856.

[18] Margaretha, M., Widiastuti R., Zaniarti S., \& Hendra W., (2018). Employee Engagement and Factors that Influence: Experiences of Lecturers in Indonesia. International Journal of Management Science and Business Administration, Inovatus Services Ltd. 4(6), 34-41.

[19] Mugenda, O. Mugenda (2009) Research Methods: Quantitative and Qualitative Approaches. Nairobi: ACTS.

[20] Mwangi, C., Mukulu, E. \& Kabare, K. (2011). The significance of emotional intelligence in transformational leadership for Kenyan public universities. International Journal of Humanities and Social Sciences, 1(7), 28-35.

[21] Nassaji H. (2015). Qualitative and descriptive research: Data type versus data analysis. Language Teaching Research.;19(2):129132. doi: $10.1177 / 1362168815572747$.

[22] Negru-Subtirica, O., \& Pop, E. I. (2016). Longitudinal links between career adaptability and academic achievement in adolescence. Journal of Vocational Behavior, 93, 163170. https://doi.org/10.1016/j.jvb.2016.02.006.

[23] Nyarko, F., Peltonen, K., Kangaslampi, S., \& Punamäki, RL. (2020). Emotional intelligence and cognitive skills protecting mental health from stress and violence among Ghanaian youth. Heliyon, 6(5), [e03878]. https://doi.org/10.1016/j.heliyon.2020.e03878.

[24] O'Connell, D. J., McNeely, E., \& Hall, D. T. (2008). Unpacking personal adaptability at work. Journal of Leadership \& Organizational Studies, 14, 248-259.

[25] Orodho, J. A. (2009). Techniques of writing research proposals and reports in education and social sciences. Nairobi. Kanezja publishers.

[26] Rocha, M. (2012). Transferable skills representations in a Portuguese college sample: Gender, age, adaptability and vocational development. European Journal of Psychology in Education, 27, 77-90.

[27] Rossier, J., Zecca, G., Stauffer, S.D., Maggiori, C., and Dauwalder, J-P. (2012). Career Adapt-Abilities Scale in a Frenchspeaking Swiss sample: Psychometric properties and relationships to personality and work engagement. Journal of Vocational Behaviour, 80, 734-743.

[28] Rostami, Z., Abedi, M.R., Bagnhan, I., and Savickas, M.L. (2012).Towards career salvation's model, a primary study: case study. Interdisciplinary Journal of Contemporary Research, 4 (2), 1133-1139.

[29] Salamonson, Y., Andrew, S., and Everett, B. (2009). Academic engagement and disengagement as predictors of performance in pathophysiology among nursing students. Contemporary Nurse: A Journal for the Australian Nursing Profession, 32,. 123- 132.

[30] Santilli, S., Nota, L., Ginevra, M. C., \& Soresi, S. (2014). Career adaptability, hope and life satisfaction in workers with intellectual disability. Journal of Vocational Behavior, 85(1), 67-74. https://doi. org/10.1016/j.jvb.2014.02.011.

[31] Savickas M. L., Porfeli E. J. (2012). Career adapt-abilities scale: construction, reliability, and measurement equivalence across 13 countries. J. Vocat. Behav. 80 661-673.

[32] Savickas, M. L. (1997). Career adaptability: An integrative construct for life-span, life-space

[33] Savickas, M. L. (2005). The theory and practice of career construction. In S. D. Brown and R.w. Lent. Career development and counseling: putting theory and research to work. Hoboken, $\mathrm{NJ}$ :John wiley and sons.

[34] Savickas, M. L. (2005). The Theory and Practice of Career Construction. In S. D. Brown \& R. W. Lent (Eds.), Career Development and Counselling: Putting Theory and Research to Work (pp. 42-70). Hoboken, NJ: John Wiley \& Sons.

[35] Savickas, M. L., \& Porfeli, E. J. (2012). Career adapt-abilities scale: Construction, reliability, and measurement equivalence across 13 countries. Journal of Vocational Behavior, 80(3), 661673. https:// doi.org/10.1016/j.jvb.2012.01.01.

[36] Van der Velden, R. K. W., \& Allen, J. P. (2011). Mobilization of human resources. In J. Allen, \& R. K. W. V. D. Velden (Eds.), The Flexible Professional in the Knowledge Society: New Challenges for Higher Education Springer. Higher Education Dynamics No. 35.

[37] Wainaina., C \& Kabare., K \& Mukulu., E (2014). Determinants of employee adaptability to transformational change in commercial in Nairobi, Kenya: Empirical review. International Journal of Academic Research in Business and Social Sciences. 4(10), 1-9.

[38] World Bank. 2019. Improving Higher Education Performance in Kenya : A Policy Report. World Bank, Washington, DC. (C) World Bank. https://openknowledge.worldbank.org/handle/10986/32361 License: CC BY 3.0 IGO. 
[39] Zacher, H. (2014). Career adaptability predicts subjective career success above and beyond personality traits and core selfevaluations. Journal of Vocational Behavior, 84, 21-30.

[40] Zhang, Y. (2010). Recent tertiary graduate's career attitudes, career adaptability, career self management behaviours: Focus on a continuity in a fragmented employment context (Unpublished master's dissertation). Massey University, Palmerston North, New Zealand. 